\title{
Possibilities of hydraulic and hydrology simulation models as support to conventional methods for the limit of hazard zones by the example of the Donnersbach stream
}

\author{
S. Janu
}

Technical Service for Torrent and Avalanche Control, Department of Styria, District Ennstal and Salzatal, Austria

\begin{abstract}
Numeric hydraulic simulation models are used successfully in the range of flood documentation and event analysis. By using these documentations, with the help of event data sets (precipitation, discharge data, water marks...), it is possible to calibrate the provided models and to gain useful knowledge of the pros and cons and their application. In addition to that, with laser scan data sets, wide land models with a high resolution can be built and used as a basis for numerical hydraulic simulations.

In the existing project, the revision of the hazard mapping Donnersbachwald resulted in the use of a numeric hydraulic simulation as a supplement to the common methods (historic method, literature-investigation, analysis of previous planning and expert opinion).

For the project "Delimitation of hazard zones at the torrent Donnersbach/Styria" two-dimensional and one-dimensional hydraulic simulation models were used in addition to the common planning methods (historical method, literature search, evaluation of past planning and appraisals).

Different scenarios were calculated, varying the input hydrograph (the hydrologic calculations were carried out with the aid of the HEC-HMS model), flooding process and blockage of bridges. The selected sections lie in the valley at the bottom of the community of Donnersbach with a slope angle of between two and five percent.

After evaluation of existing data sets with the help of historical event data in principle, two questions for the simulation resulted:

1. The effect of blockage of existing bridges for the overland flow.

2. Retardation of flow due to the storage effect of overland flow for the main stream in Donnersbach.

With the two-dimensional numerical simulation the reciprocal effects of the subordinated processes and different discharge scenarios could be considered and analyzed. The results were used on one hand as a support instrument for the delineation of hazard zones and on the other hand as documentation material for the public work.

Keywords: flood discharge, numeric 2-d simulation, delineation of hazard zones.
\end{abstract}




\section{Introduction}

Today critical natural events, for example floods, are experienced as disasters by the public as they frequently cause huge damage. This is due to the fact that financial and material assets are affected and at the same time rising prosperity and a high quality of life create a greater need for protection among the population.

To improve protection, natural hazards (such as torrents, avalanches, slides, and rockfalls) are considered in development plans. This is done with the help of hazard maps, which are provided by the Technical Service for Torrent and Avalanche Control. By legal definition these hazard maps are only experts' opinions (usually for a local community), but as they are embodied in the local development plans they become legally binding. The provincial development and building laws include regulations that limit development sites that are endangered by natural hazards. The mapping of hazard zones enables the authorities to accurately evaluate the potential danger of any plot so that necessary provisions to make the site safe can be taken.

As the concepts and models of natural hazard analysis are constantly being adapted - a lot has changed since the beginning of hazard zone planning - it is necessary to test and update the latest technology in practice (Schmid [1]).

When the hazard map of Donnersbachwald was revised, new methods such as numeric hydraulic 2-D and 1-D simulations were used in addition to common methods (historical method, literary research, evaluation of past planning and experts' report).

\section{Initial position and problem definition}

The hazard map of the community of Donnersbachwald had to be revised as it was several years old. In this paper I will specifically deal with the demarcation of the hazard zones by the torrent of Donnersbach. This torrent has a catchment area of approx. $115 \mathrm{~km}^{2}$ and a calculated HQ150 of approx. $200 \mathrm{~m}^{3} / \mathrm{s}$. The torrent runs along the bottom of the Donnersbach valley and has an average gradient of approximately $4 \%$. From the expert's point of view this torrent does not have the potential to cause a debris flow, however in the case of a flood there might be strong sediment flow from lateral erosion and debris in the form of fallen trees. The river flows through the center of Donnersbachwald, where numerous bridges support the existing infrastructure.

In the course of the revision of the hazard map, the area was topographically surveyed and existing data was evaluated with regard to historic knowledge. Thus possible processes and scenarios in the case of a flood could be determined. Basically two questions came up:

1. How does the blockage of the bridges by fallen trees affect agricultural areas, settlement areas and infrastructure facilities next to the torrent?

2. How do flooded surfaces due to flow retention affect the total discharge hydrograph curve of the main stream? 


\section{Objectives}

Since the questions quoted above could neither be completely clarified by means of the historical method, nor by the analysis of the existing data bases and expert knowledge, the planner made use of state-of-the-art technology and simulation techniques. With the help of a 2-d (and 1-d) numeric simulation model the effects of the defined scenarios were calculated, and the results could serve to define the demarcation of the hazard zones more accurately.

\section{Methods}

With the help of a detailed topographic survey of the area, an evaluation of historical data (photographs, chronicle recordings etc. ...) and a hydrologic computation with the determination of the HQ150, as well as the determination of sediment discharges and debris accumulation, the basis for the definition of the simulation sections and possible scenarios was laid. For the production of the digital terrain model laser scans were used, so that large areas could be depicted in meticulous detail. In places where floods are likely to occur buildings were also included in the digital terrain model.

The definition of possible scenarios (blockage of bridges...) was based on expert opinions and historical events. As a simulation model the twodimensional numeric drainage model FLO-2D (and 1D HEC-RAS) was used.

\section{Hydraulic simulation and scenarios}

\subsection{Digital terrain model and base data for the simulation}

The creation of the terrain model was based on $1 \times 1 \mathrm{~m}$ laser scan data. From these basic data in the ARC GIS a TIN was provided and in a further step the buildings were installed in the simulation section. Mapping the channel and floodplain roughness took place in the course of the topographic survey.

The hydraulic input data was derived from flood calculations including a probability of return of 150 years (HQ150), with a discharge point of $167 \mathrm{~m}^{3} / \mathrm{s}$ in the regarded channel section.

\subsection{Scenario 1 - blockage of bridges and flooding of the adjacent settlement}

This scenario contains a total blockage of a bridge due to wooden debris and sediment transport which is classified as "highly probable" in this section.

For the simulation of the blockage the grid cells were extended as far as the upper bridge edge.

\subsection{Scenario 2 - impact of the flow retention}

The effects of the flow retention are only assessable with difficulty, therefore the definition of retention areas is only possible with some reservations. Thus the 


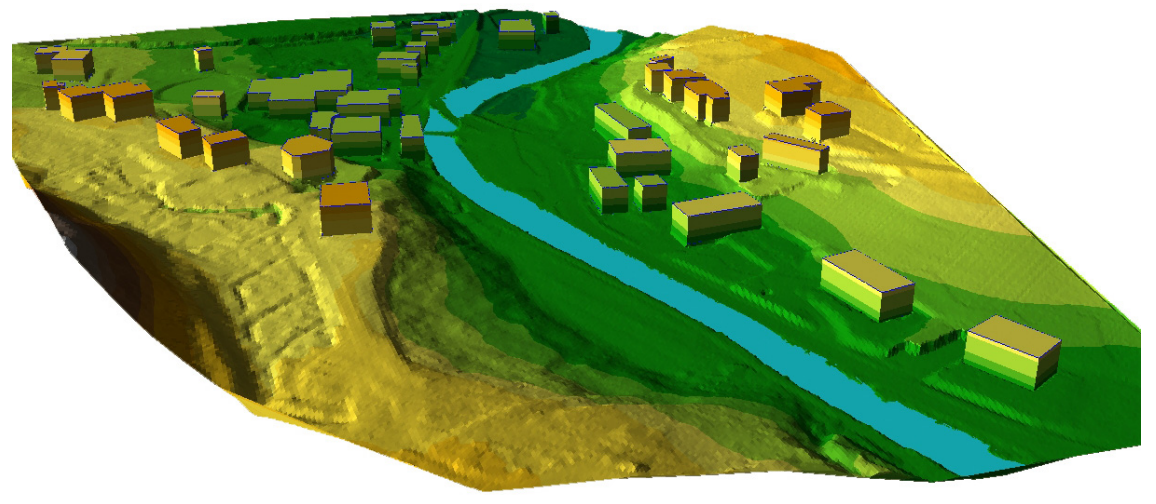

Figure 1: Overview with the Donnersbach, blockage at the bridges and surface model building in 3D opinion.

calculation of the effects was attempted with the help of a 2-D simulation to assist in defining a possible demarcation.

\section{Results}

\subsection{Scenario 1 - blockage of bridges}

The result of the simulated blockage showed a clear backwater of the settlement at the left coagulating side. In comparison with the result of the topographic survey and the evaluation of a terrestrial determination of the backwater line (notice line) a very good agreement with the simulation result could be obtained.

\subsection{Scenario 2 - impact of the flow retention}

The comparison of the entrance hydrograph curve [ INFLOW ] with the discharge hydrograph curve [ OUTFLOW ] at the end of the simulation section showed a slight reduction of the peak discharge (approximately $2 \%$ of the HQ150) and a small temporal delay of the discharge point (approximately 15 $\min )$.

\section{Conclusion}

With the help of numeric 2-D models the planner has an additional state-of-theart tool to define the hazard zones.

In this project a valuable method to increase accuracy with the help of a simulation at selected coagulating sections and by defining possible scenarios (blockage...) was introduced. 


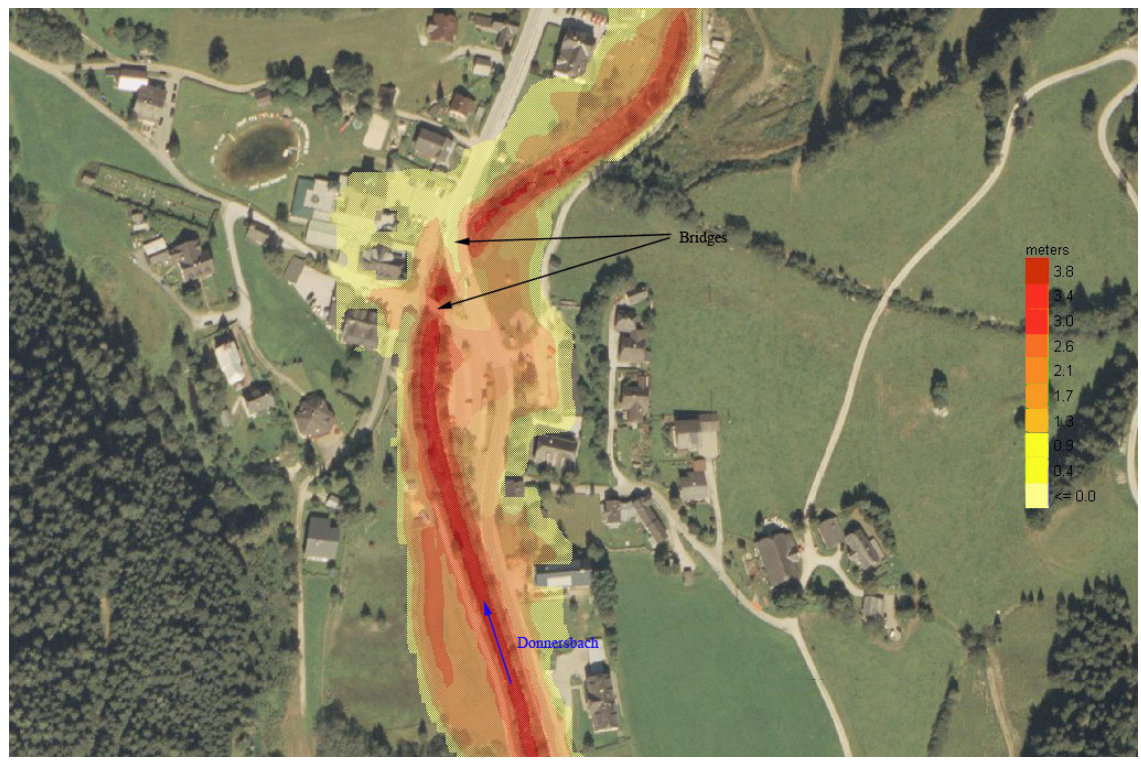

Figure 2: Result scenario blockage of the bridges with the backwater into the settlement.

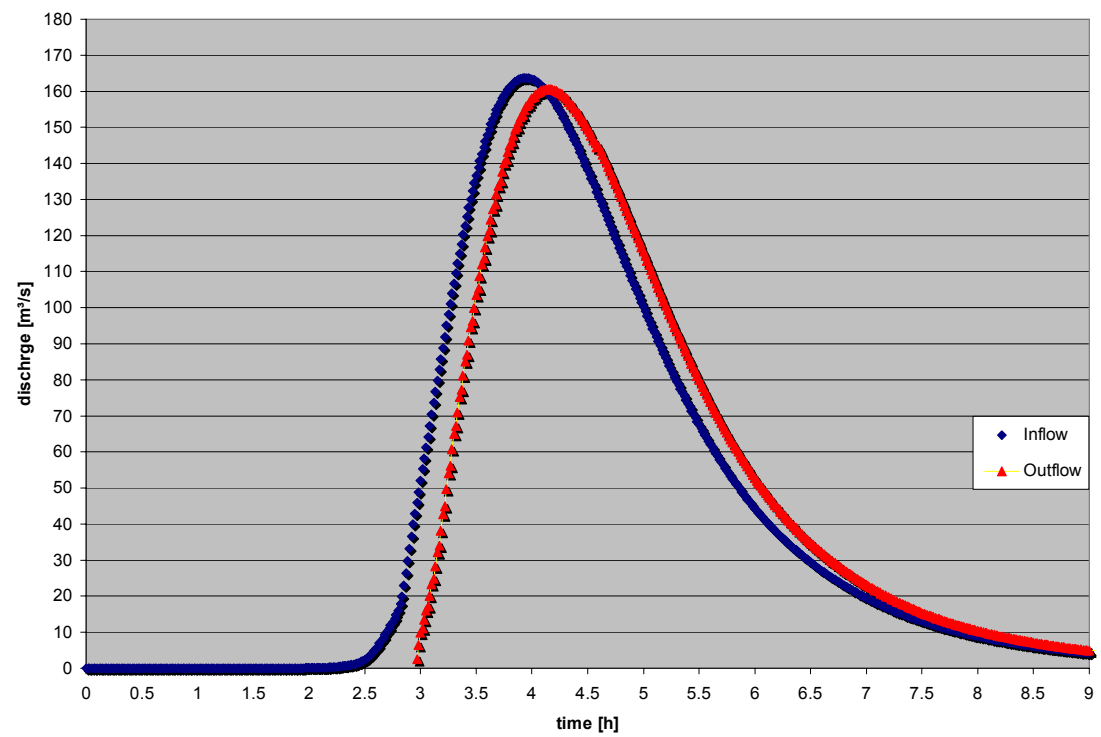

Figure 3: Result of the examined flow retention in the regarded simulation section. 
However, utmost care and high expert knowledge are necessary, to use the models correctly on the one hand, and - perhaps even more importantly - to be able to define the necessary input data and scenarios (process definition, choice of the input data, plausibility checks) on the other hand.

\section{Final consideration and future prospects}

A simulation should be used as an additional tool to increase the accuracy accordingly. Only comprehensible scenarios, transparent input data (DHM, flow roughness...) as well as an interpretation and a critical analysis of the results make this tool an important and valuable aid.

In the project of revising a hazard map it became obvious that "expert knowledge", topographic surveying and analysis, the inclusion of all historical data (chronicle events), the definition of scenarios and the selective use of simulation models make a comprehensive evaluation possible.

\section{References}

[1] Schmid, F. (2007): Die berücksichtigung der Wirkung von Schutzbauweken in der Gefahrenzonenplanung - einige Grundsatzüberlegungen. In: Zustandserfassung, Instandhaltung und Sanierung von Schutzbauwerken der Wildbach- u. Lawinenverbauung, Heft. Nr. 155, June 2007

[2] Hübl, J., Leber, D., Brauner, M., Janu, S., Volk, G., Holzinger, H., Gruber, H. (2004): Dokumentation der Unwetterereignisse in den Gemeinden St. Stefan/Vorderberg und Feistritz an der Gail vom 29. August 2003, IAN Report 99, Institut für Alpine Naturgefahren, Universität für Bodenkultur Wien. Im Auftrag der WLV Sektion Kärnten .

[3] Hübl, J., Loiskandl; W., Gruber, H., Holzinger, G., Janu, S., Kraus, D., Moser, M., Pichler, A., Weiser, D., Zott, F. (2004): Hochwasserschutz durch die Reaktivierung von Überflutungsräumen - Evaluierung des Systemverhaltens im Verbauungsprojekt „Pertisauer Wildbäche“: Simulation des Abflussgeschehens und Monitoring- und Warnsystem Pertisau; IAN Report 76 Band 4, Institut für Alpine Naturgefahren, Universität für Bodenkultur Wien. Im Auftrag der WLV Gbltg. Westliches Unterinntal.

[4] Hübl, J., Janu, S. (2003): Dokumentation und Analyse der Hochwasserereignisse vom 6. bis 12. August 2002 im nördlichen Niederösterreich, WLS Report 96, Institut für Alpine Naturgefahren, Universität für Bodenkultur Wien. Im Auftrag der WLV Sektion Wien, Niederösterreich und Burgenland .

[5] Janu, S. (2006): Hazard map of the community Pichl- Kainisch, province Styria, Austria.

[6] Janu, S. (2007): Hazard map of the community Tauplitz, province Styria, Austria. 